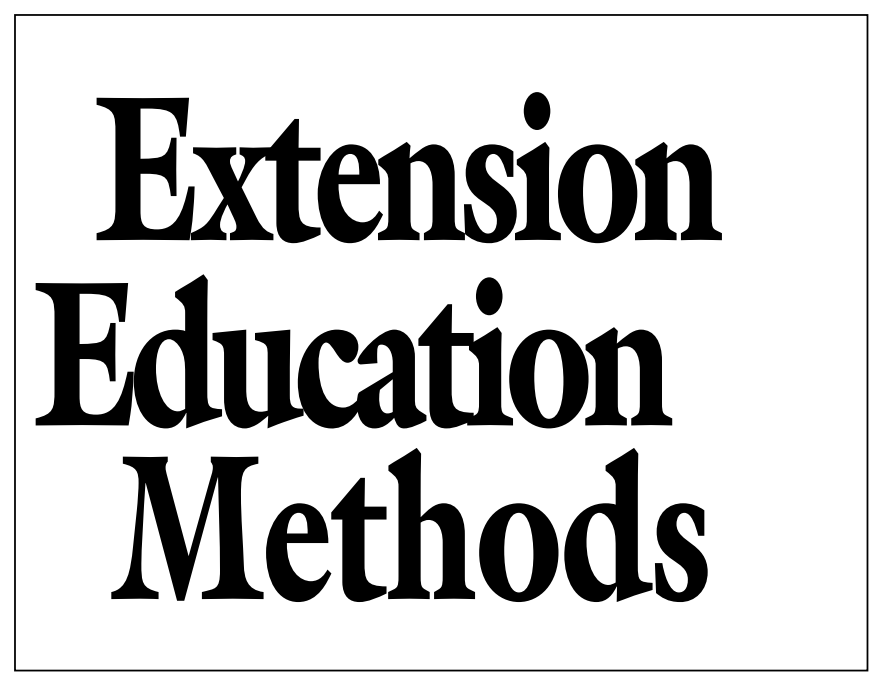

\section{Developing a Plant Clinic Database as an Educational and Predictive Tool for Master Gardener Programs}

\author{
Larry Joh ${ }^{1}$ and David V. Barkley ${ }^{2}$
}

Additional InDeX wORDs. cooperative extension, volunteer, computer, data analysis, diagnosis, plant disease, insect identification

Summary. The North Carolina Cooperative Extension Service's New Hanover County Center provides the Plant Disease and Insect Clinic staffed by the Horticulture Extension Agent and Master Gardener volunteers. Residents bring in samples of weeds, diseases, and insects for identification and control recommendations. After the problem is diagnosed, a record of the information is used to construct a database that includes the date, phone number, crop, diagnosis, and control for each sample submitted. Between January 1993 and December 1999, Master Gardener volunteers entered more than 4,000 entries into a searchable/sortable electronic database to identify patterns of plant disorders. The database should be a useful tool for predicting local disease and insect cycles and aiding Master Gardeners in answering questions at the clinic and over the telephone. In addition, examination of historical records and entry of data into the database are excellent learning opportunities for new Master Gardeners.

Data input by Master Gardeners: Karen Besaw, Kay Boone, Larry Joh, Lisa Skemp, Jennifer Tarplee, and Sandy Utley, New Hanover County. Recommendations for the use of agricultural chemicals are included in this publication as a convenience to the reader. The use of brand names and any mention or listing of commercial products or services in this publication does not imply endorsement by North Carolina State University nor discrimination against similar products or services not mentioned.The cost of publishing this paper was defrayed in part by the payment of page charges. Under postal regulations, this paper therefore must be hereby marked advertisement solely to indicate this fact.

${ }^{1}$ Master Gardener and database coordinator, New Hanover County Cooperative Extension, 6206 Oleander Drive, Wilmington, NC 28403.

${ }^{2}$ Horticulture extension agent, New Hanover County Cooperative Extension, 6206 Oleander Drive, Wilmington, NC 28403
C ooperative extension agents and Master Gardener volunteers provide helpful advice to county residents on a variety of topics. Many cooperative extension offices have trained staff available to answer questions over the telephone or to examine specimens submitted to a plant clinic. An extension agent is aware of crops that have persistent problems in his or her area, the problems that are being identified, and current recommendations for these problems. To effectively evaluate trends, an extension agent needs historical and current information on the crops, diagnoses, controls, and locations of disease, insect, and weed problems. This knowledge allows the extension agent to focus on recurring issues, minimize pesticide resistance (by rotating pesticide recommendations), tailor educational programs, and be proactive rather than reactive. The information also provides educational benefit for novice as well as experienced Master Gardeners.

Master Gardeners are required to complete a training program and a specified number of volunteer hours. Simonson and Pals (1990) found that the most common reason individuals become Master Gardeners is a desire to increase their gardening knowledge for their own use, while Schrock et al. (2000) found that they want to learn more about horticulture and home gardening. The training program combines a training manual and hands-on exercises with an overview of horticultural subjects pertinent to the students' geographic area. While this training forms a firm foundation, successful Master Gardeners further their horticultural skills by finding answers to clients' questions and performing other volunteer work. Service learning, obtained from active participation in addressing community needs, is an effective form of Extension education (Simpson, 1998).

Answering questions on a hotline or at a plant clinic is a difficult task for a new, inexperienced Master Gardener. Some cooperative extension offices have customized resource manuals that provide answers to common questions received by telephone (Patterson, 1995). Master Gardeners can accelerate their learning and build confidence through mentoring by an extension agent or a more experienced Master Gardener (Rogers, 1997; Phillips and Bradshaw, 1999). Another way to build skills is to review documentation of how past plant problems were handled. However, it is rarely possible to examine past horticultural records and gain this knowledge with ease. While a client is waiting on the telephone or in person, wading through a mountain of records to find an appropriate answer to the question is not feasible.

A computer database can help Master Gardeners learn and disseminate information more accurately and quickly and serve an extension agent's need to analyze trends in horticultural problems. The objectives of the database project were 3-fold: 1) develop a suitable database platform for the North Carolina Cooperative Extension Service's New Hanover County Center Plant Disease and Insect Clinic records that could be sorted by different criteria and analyzed for trends; 2 ) use data entry as a learning activity for new Master Gardeners; and 3) use information from the database to improve the Master Gardener training course and better prepare volunteers to answer clinic questions. In addition, the database can be searched on-line to answer questions and help predict insect and disease problems. 
Table 1. Example of the New Hanover County, N.C., plant clinic database entries, sorted first by crop, then by diagnosis, then by date. ${ }^{\mathbf{z}}$

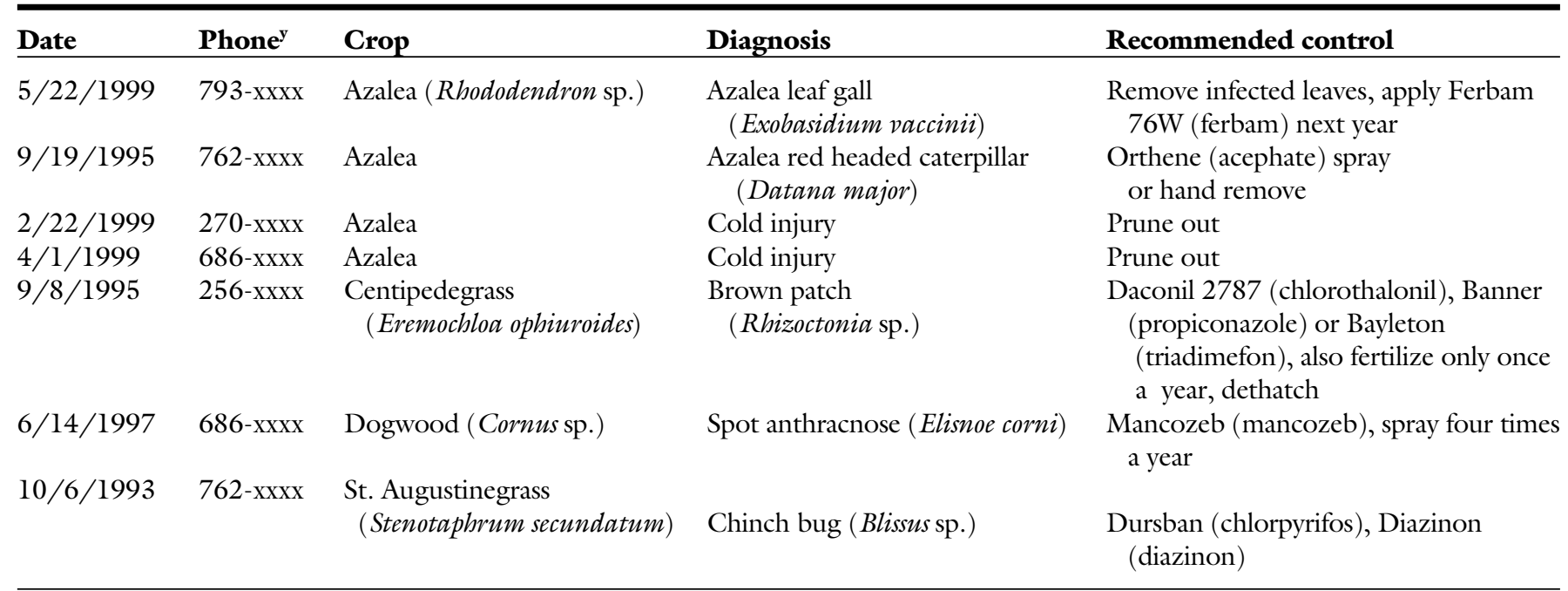

${ }^{\mathrm{z} F o r}$ each insect, disease, or weed sample, the date, client phone number, affected crop, brief diagnosis, and brief control recommendation are recorded in the database. Genus, species, and chemical names are not included in the database, but are included here for reference. The database can be sorted by other user-selected criteria.

yFull 7-digit phone numbers are included in the database.

\section{Procedures}

Database platform selection. The first step in the project was to select the database software. The criteria for selection included 1) compatibility with the Master Gardeners' home software, so the data entry can be done at home; 2 ) simplicity of data entry and use; 3 ) sorting by date or text fields, with multiple-criteria sorting; 4) key word or phrase search function; and 5) compatibility with software in use at the New Hanover County Center. True database software was considered the most logical option for this application. However, the center had neither specialized database software available nor a desire to maintain it, so this option was ruled out.

The method chosen after some experimentation required volunteers to enter the data using a popular word processing program, such as Microsoft Word. This method met criteria $1-4$. Criterion 5 was not met, because the New Hanover County Center had, at the time the project was conceived, a different word processing program on their network. The conversion between some versions of the two programs alters formatting. In the case of the versions of the two particular brands of software, formatting and search capability were preserved.

The plant clinic database was structured as a table. The software features allow the table to be sorted by columns, using a hierarchical routine. For example, using the "Sort" feature, a table containing five columns can be sorted first by the contents of column three, then by the contents of column two, and finally by the contents of column one. For each column, the user has the choice of sorting by date, number, or text, and either ascending or descending order. By using the "Replace All" feature, and replacing a word

Table 2. Percent occurrence of most commonly affected crops, diagnosed problems, and recommended controls during $1993-99$ for the New Hanover County, N.C., area. ${ }^{z}$

Rank

Most commonly affected crops, in rank order
1
2
3
4
5

Most commonly diagnosed problems, in rank order

1
2
3 (tie)
3 (tie)
5

Most commonly recommended controls, in rank order

1

2

3

4

5
Percent

Crop
Centipedegrass (Eremochloa ophiuroides)
Azalea (Rhododendron sp.)
St. Augustinegrass (Stenotaphrum secundatum)
Dogwood (Cornus sp.)
Holly (Ilex sp.)
Diagnosis
Fungal leaf spot (e.g., Septoria, Entomosporium sp.)
Heat damage
Brown patch (Rhizoctonia sp.)
Cold/winter damage
Scale insect (e.g., Lecanium, Lepidosaphes sp.)
Control
Daconil (chlorothalonil)
Prune damage
Orthene (acephate)
Horticultural (petroleum) oil
Dursban (chlorpyrifos)

\section{4}

6.7

5.4

4.9

3.5

\section{3}

6.5

6.4

6.4

5.1

11.4

10.8

9.1

5.4

3.4

${ }^{\mathrm{z}}$ Expressed as a percentage of total entries of all types $(4,107)$ in the database. 
Table 3. Number of entries in the database and most commonly diagnosed problem by calendar month during $1993-99$ for the New Hanover County, N.C., area.

\begin{tabular}{lcl}
\hline Month & Entries(no.) & Mostcommon diagnosis \\
\hline January & 82 & Fungal leaf spot (e.g., Septoria, Entomosporium sp.) \\
February & 142 & Fungal leaf spot (e.g., Septoria, Entomosporium sp.) \\
March & 295 & Cold/winter damage \\
April & 421 & Cold/winter damage \\
May & 623 & Brown patch (Rhizoctonia sp.) \\
June & 773 & Heat damage \\
July & 597 & Heat damage \\
August & 485 & Heat damage \\
September & 257 & Heat damage/fungal leaf spot (e.g., Septoria, Entomosporium sp.) \\
October & 230 & Brown patch (Rhizoctonia sp.) \\
November & 160 & Scale insect (e.g., Lecanium, Lepidosaphes sp.) \\
December & 42 & Scale insect (e.g., Lecanium, Lepidosaphes sp.) \\
Total entries & 4,107 & \\
\hline
\end{tabular}

${ }^{z}$ Total entries in the database, derived from about 5,000 plant clinic forms.

with the same word, the program will tally the number of occurrences of that word in the database, which is handy for generating statistics. The "Find" feature of the word processing software also allows searching for a word or phrase anywhere within the table, permitting quick reference.

Data entry. When a Master Gardener cannot solve a problem brought into the clinic, he or she completes a form. (For questions that are easily answered, no form is completed, but the Master Gardener Program Coordinator provides monthly summaries of the most frequently asked questions and their answers.) The form contains the following information: crop, county, and date planted/collected; client name, address, and phone number; plant parts affected, symptoms, and insect data. The plant, disease, or insect sample is retained with the form. The diagnosis and control recommendation are later written on the bottom of the form, along with the date diagnosed, by another Master Gardener or the extension agent. If the extension agent is unable to determine the problem, the sample is sent to the North Carolina State University Plant Disease and Insect Clinic for diagnosis. Finally, a Master Gardener calls the client, informs him or her of the diagnosis and control, and adds the date called to the form.

About 5,000 forms were completed from 1993-99. The database coordinator divided the forms among the coordinator and five newly trained Master Gardeners. Each volunteer used his or her home computer to input the data, following instructions and using an electronic template to minimize inconsistencies in data format and content. Each portion of the database was saved to the same version of the word processing software, and e-mailed to the coordinator to compile.

Data validation. Since inconsistencies (e.g., synonyms, scientific versus common names) or misspellings would lead to errors in searching or sorting, the coordinator reviewed and corrected the combined database. Entries were standardized so each line contained only one crop and one diagnosis. In each case where one crop had two unrelated diagnoses, or two crops had the same diagnosis, the case was rerecorded as two entries. Forms with no specific diagnosis (or for ornamental plant identification only) were omitted; however, forms with no phone number, crop, and/or control were included to maximize potentially useful diagnostic data. The validated database yielded 4,107 entries.

Table 4. Comparison of number of reported turfgrass problems by grass type, reported during $1993-99$ for the New $\mathrm{Hanover}$ County, N.C., area.

\begin{tabular}{|c|c|c|c|c|c|c|c|c|}
\hline Problem & Centipedegrass $^{z}$ & St. Augustinegrass ${ }^{y}$ & Zoysiagrass $^{x}$ & Bermudagrass $^{w}$ & Carpetgrass $^{\mathbf{v}}$ & Fescue $^{\text {u }}$ & Bahiagrass $^{\text {t }}$ & Lawn $^{\text {s }}$ \\
\hline \multicolumn{9}{|l|}{ Brown patch } \\
\hline (Rbizoctonia sp.) & 132 & 64 & 8 & 5 & 1 & 1 & 0 & 42 \\
\hline \multicolumn{9}{|l|}{ Ground pearl } \\
\hline (Margarodes sp.) & 57 & 13 & 1 & 2 & 0 & 0 & 0 & 13 \\
\hline \multicolumn{9}{|l|}{ Chinch bug } \\
\hline (Blissus sp.) & 1 & 59 & 0 & 0 & 0 & 0 & 0 & 6 \\
\hline \multicolumn{9}{|l|}{ Mole cricket } \\
\hline (Scapteriscus sp.) & 7 & 0 & 2 & 2 & 0 & 0 & 0 & 3 \\
\hline Total problems ${ }^{\mathrm{r}}$ & 387 & 223 & 60 & 41 & 8 & 3 & 1 & 154 \\
\hline $\begin{array}{l}{ }^{2} \text { Eremochloa ophiuroide } \\
\text { y Stenotaphrum secunda } \\
{ }^{\mathrm{x}} \text { Zoysia japonica } \\
{ }^{\mathrm{w}} \text { Cynodon sp. } \\
{ }^{\mathrm{v}} \text { Axonopus affinis } \\
{ }^{\mathrm{u}} \text { Festuca sp. } \\
{ }^{\mathrm{t}} \text { Paspalum notatum } \\
{ }^{\mathrm{s}} \text { Unspecified lawn type } \\
\text { rTotal problems also in }\end{array}$ & $\begin{array}{l}\text { les } \\
\text { atum }\end{array}$ & 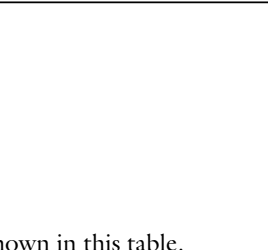 & & & & & & \\
\hline
\end{tabular}


Table 5. Most commonly reported problems [number (\%)] for cities in the New Hanover County, N.C., area during 1993-99. ${ }^{\mathrm{z}}$

\begin{tabular}{|c|c|c|c|c|c|c|}
\hline Location $^{y}$ & Entries (no.) ${ }^{x}$ & Brown patch $^{\text {w }}$ & Fungal leafspot ${ }^{\mathrm{v}}$ & Colddamage & Heat damage & Scale Insect ${ }^{\mathrm{u}}$ \\
\hline Scotts Hill & 548 & $29(5.3)$ & $46(8.4)$ & $42(7.7)$ & $39(7.1)$ & $24(4.4)$ \\
\hline Carolina Beach & 82 & $7(8.5)$ & $8(9.8)$ & $4(4.9)$ & $5(6.1)$ & $7(8.5)$ \\
\hline Castle Hayne & 68 & $8(11.8)$ & $2(2.9)$ & $4(5.9)$ & $1(1.5)$ & $4(5.9)$ \\
\hline
\end{tabular}

${ }^{\mathrm{z}}$ For each problem, the number of times that problem is reported for each location is shown, with the corresponding percentage based on the total number of problems for that location.

yGeographic location based on telephone prefix.

${ }^{x}$ Total number of problems reported for a given geographic location.

${ }^{\mathrm{w}}$ Rhizoctonia sp.

ve.g., Septoria, Entomosporium sp.

ue.g., Lecanium, Lepidosaphes sp.

\section{Results}

The database was designed with the date diagnosed in column one, client phone number in column two, crop in column three, brief diagnosis in column four, and brief control recommendation in column five. The database was initially sorted by each column, with each of the five sorted versions of the database saved to a separate file on a CDROM. Table 1 provides a sample from the sorted database, showing the entries sorted alphabetically, first by crop, then by diagnosis, then in ascending order by date. Sorting the database as shown in Table 1 entails the following steps: 1 ) place the cursor within the table; 2 ) select "Sort" under the "Table" menu; and 3 ) in the "Sort" menu, select "Sort by Column 3, Type: Text, Ascending," "Then by Column 4, Type: Text, Ascending," and "Then by Column 1, Type: Date, Ascending." An analogous process can be used with other word processing programs. A paper copy of the database was provided to the plant clinic for occasions when the computer is unavailable. This copy includes the three most useful sorted versions (by crop-diagnosis-date, by diagnosis-crop-date, and by month-crop-diagnosis-date) as well as pertinent statistics.

Database statistics and trends. The database can be sorted and analyzed in many ways. A query, based on any combination of the data in the five columns [e.g., all occurrences of yellowish birch aphids (Calaphisbetulaecolens) on river birch (Betula nigra) in 1995 where Orthene (acephate) was recommended], can be developed. Inspection of the sorted database is needed when the query word or phrase is not at the beginning of the entry. Alternatively, the "Find" feature can be used to sequentially locate all entries containing the query word or phrase to generate statistics. Patterns emerge from the data based on frequency, combinations, distribution, and timing; these trends can be analyzed to predict future problems. The following tables are examples of statistics and trends that can be derived from the database.

Table 2 lists the most frequently received crops, most common diagnoses, and most often recommended controls. Centipedegrass (Eremochloa ophiuroides), the most common turfgrass in southeastern North Carolina, was submitted most frequently. Fungal leaf spots (e.g., Septoria, Cercospora, Entomosporium sp.) and brown patch (Rhizoctonia sp.) were two of the most commonly diagnosed problems. A fungicide, Daconil 2787 (chlorothalonil), registered for control of these problems, was the most often recommended control. Pruning out the diseased or infested part of the plant was the second most common control recommended.

Table 3 illustrates month-by-month variation, showing the most common problem for each month. The data show cycles of when disease and insect problems arise. Master Gardeners can use the month-by-month data as a predictive tool in anticipating client questions. Table 3 also shows the number of plant clinic entries by month. These data show a peak in usage during June, and can be used to help determine staffing needs for the plant clinic.

Table 4 exemplifies how the database can be used for multiple comparisons. The four most common turfgrass problems are tabulated according to the types of turfgrass. These data can supplement literature advice on susceptibility of turfgrasses to insects and disease.

Table 5 shows the number of users of the plant clinic by geographic location. Since the forms do not reliably include an address or zip code, the client telephone prefix was used as a general guide to location. People in Wilmington, the largest city in New Hanover County, N.C., are the most frequent users of the plant clinic. Table 5 also maps the distribution of the top five problems (from Table 2) among the top five geographic locations.

\section{Discussion}

Educational tool. Development of the plant clinic database was an excellent learning tool for those Master Gardeners involved. By inputting the data, new Master Gardeners assimilated information on local gardening and gained confidence in diagnosing problems. Data entry, though repetitious, provides effective training on a wide variety of issues. New and experienced Master Gardeners alike can benefit from the quick reference the database provides. The database can also be shared with clients, and the data provided may encourage more questions. The Master Gardener training program can include instruction on use of the database. This tool can be shared with others in the horticultural field through presentations.

Predictive tool. Many requests are made for information dealing with outbreaks of insects, diseases, and other plant production problems. Data collected over the years and entered into the database are useful for determining recent histories of pest occurrences, thus aiding the extension agent in forecasting common pest problems. The data can be used in advanced training sessions for Master Gardeners, or for developing news articles, media interviews, and fact sheets for this area of North Carolina. The data can also be used to prepare agents and volunteers on how to handle these problems in a more professional, proactive way. In this case, the data provide an opportunity to warn citizens of possible threats and to recommend actions they can take to lessen the severity. 
Limitations. The database, while a useful tool, has limitations and problems which include: incomplete plant clinic forms, software incompatibility, and time required to incorporate reports from previous years. Easily answered questions are not included in the database. Perhaps the most severe limitation is that past recommendations for control may no longer be applicable. Pesticides may be relabeled, disallowing prior uses of the products. For example, the registration uses of Dursban (chlorpyrifos), the fifth most often recommended control, have recently changed. Users of the database must confirm their diagnoses and check their current references before making pesticide recommendations.

Future USES. This article presents only a few examples of the data analysis types possible with a plant clinic database. Other correlations and trends can be examined. Tools such as a month-by-month guide for regional insect, disease, and weed problems could be developed using the database. Telephone numbers in the database allow contacting past clients to determine the efficacy of the recommendation and satisfaction with clinic service. Posting the database on the Internet may allow the data to be shared more widely. New Master Gardeners will be recruited to continue building the database.

\section{Conclusion}

The project was a success that enabled new Master Gardeners to accelerate their learning about local plant disease, insect, and weed problems. Master Gardeners and extension agents at New Hanover County now have seven years of data at their fingertips to aid in answering horticultural questions and predicting future pest trends. For others who may want to develop similar databases, the keys to success are a leader who values the project and dedicated volunteers to input and evaluate the data. The database has limitations, but contains a wealth of information in readily accessible form.

\section{Literature cited}

Patterson, D. 1995. Master Gardener phone response manual. J. Ext. 33(5). Oct. 1995. 14 June 2001. http://joe.org/joe/ 1995october/tt4.html.

Phillips, W. and J. Bradshaw. 1999. Florida Master Gardener mentor program: A case study. J. Ext. 37(4). Aug. 1999. 14 June 2001. http://joe.org/joe/1999august/rb3.html.

Rogers, B. 1997. Developing a successful mentoring program for volunteer training. J. Ext. 35(5). Oct. 1997. 14 June 2001. http:/ /joe.org/joe/1997october/ttl.html.

Schrock, D.S., M. Meyer, P. Ascher, and M. Snyder. 2000. Reasons for becoming involved as a Master Gardener. HortTechnology 10(3):626-630.

Simonson, D. L. and D. A. Pals. 1990. Master Gardeners: Views from the cabbage patch. J. Ext. 28(2). Summer 1990. 14 June 2001. http://joe.org/joe/1990summer/rb3.html.

Simpson, G. 1998. Extension is not just service, but service learning is important to Extension. J. Ext. 36(5). Oct. 1998. 14 June 2001. http://joe.org/joe/1998october/comml.html.

\section{Junior Master Gardener Programs in Minnesota}

\author{
Mary Hockenberry Meyer, \\ Nancy Neil Hegland, ${ }^{2}$ and Peggy Fairbourne ${ }^{3}$
}

Additional IndeX words. teaching, careers, youth, school gardens

Summary. A new gardening curriculum, developed by Texas $A \& M$ University, the Junior Master Gardener ${ }_{S M}\left(J_{M G}\right)$ program, has been taught in several locations in formal and informal settings in Minnesota. Two projects are outlined here, one an after-school program offered through a community education program, and the other a traditional elementary school setting. With hands-on activities and leader presentations, students learn horticulture as well as language arts, science, mathematics, and social science and are encouraged to volunteer in a community service project within each unit. Students reported they shared the information with their family and friends; most indicated more of an interest in gardening and horticulture after the classes. Teachers may find the curriculum helpful in developing environmental sensitivity and career interests in horticulture.

$\mathrm{C}$ urriculum for teaching horticulture in grades $\mathrm{K}$ through 12 , especially grades 7 through 12 is limited. Grow-Lab, sponsored by the National Gardening Association (Burlington, Vt.), has been one of the few programs available nationwide for teaching plant science in elementary schools (Pranis and Cohen, 1995). In 1999, Texas A\&M University introduced the $\mathrm{JMG}_{\mathrm{SM}}$, a curriculum written primarily for grades 3 through 6 (Welsh et al., 1999). $\mathrm{JMG}_{\mathrm{SM}}$ is composed of eight units: plant growth and development; soils and water; ecology and environmental horticulture; insects and diseases; landscape horticulture; fruits and nuts; vegetables and herbs; and life skills and career exploration (Whittlesey et al., 1999). Each unit concludes with suggestions for students to do volunteer community service based on the activities of that particular unit. The service component of this curriculum is patterned after the Master Gardener program (Bobbitt, 1997). The goals of the program are to build leadership, self-confidence, and foster a positive academic learning environment (Welsh et al., 1999). The objectives of this project were to 1 ) determine the suitability of the $\mathrm{JMG}_{\mathrm{SM}}$ curriculum at the Bryn Mawr Elementary School in Minneapolis and Rice County after-school program in Northfield, Minn., and 2) evaluate the curriculum for recommendation to other youth programs across Minnesota.

\footnotetext{
This research has been supported in whole or in part by the Minnesota Agricultura Experiment Station. The terms Junior Master Gardener and JMG are service marks of Texas Agricultural Extension Service. The cost of publishing this paper was defrayed in part by the payment of page charges. Under postal regulations, this paper therefore must be hereby marked advertisement solely to indicate this fact.

${ }^{1}$ Associate professor

${ }^{2}$ Extension educator.

${ }^{3}$ Master Gardener.
} 